\title{
PENGARUH MOTIVASI ANGGOTA, MANAJEMEN KEANGGOTAAN, DAN PARTISIPASI ANGGOTA TERHADAP KEBERHASILAN USAHA KOPERASI WANITA DI KABUPATEN SUBANG
}

\author{
EFFECT OF MEMBER MOTIVATION, MEMBERSHIP MANAGEMENT, AND MEMBER \\ PARTICIPATION TO BUSINESS SUCCES WOMEN COOPERATIVE IN SUBANG REGENCY
}

\author{
Sri Harini ${ }^{1)}$; Agit Septiansyah ${ }^{2)}$
}

Program Studi Manajemen Fakultas Ekonomi Universitas Djuanda Bogor Email: sri.harini@unida.ac.id; agitseptian4707@gmail.com

\begin{abstract}
This research aims to find out and identify the effect of member motivation, membership management, and member participation both simultaneously or partially on the cooperative business success of women cooperative in the Subang regency. The method of analysis used in this research is descriptive and verifikatif method. The results showed that the variables of member motivation, membership management, and member participation simultaneously or partially have an effect on the cooperative business success of women cooperative in the Subang regency.
\end{abstract}

Keywords: Member motivation, membership management, member participation, cooperative business success.

\begin{abstract}
ABSTRAK
Penelitian ini memiliki tujuan untuk mengetahui serta mengidentifikasi pengaruh motivasi anggota, manajemen keanggotaan, dan partisipasi anggota secara simultan maupun secara parsial kepada keberhasilan usaha koperasi wanita di Kabupaten Subang. Metode analisis dalam penelitian ini yaitu memakai metode deskriptif dan verifikatif. Hasil penelitian yang sudah dilaksanakan memperlihatkan bahwa variabel motivasi anggota, manajemen keanggotaan, dan partisipasi anggota secara simultan maupun secara parsial berpengaruh terhadap keberhasilan Koperasi Wanita (Kopwan) di Kabupaten Subang.
\end{abstract}

Kata Kunci: Motivasi anggota, manajemen keanggotaan, partisipasi anggota, keberhasilan usaha koperasi.

\section{PENDAHULUAN}

Indonesia sebagai negara berkembang di dunia terus mengupayakan pembangunan nasional yang merupakan indikator keberhasilan suatu negara, terutama dalam hal pembangunan ekonomi. Berbagai macam cara dan kebijakan yang diambil dan telah direalisasikan oleh pemerintah diharapkan mampu mendukung dan memperbaiki hal tersebut, karena salah satu hal terpenting yang perlu diwujudkan dalam sebuah negara adalah pembangunan ekonomi nasional. Maka salah satu lembaga atau badan usaha yang tidak dapat dilepaskan dari pembangunan ekonomi tersebut adalah koperasi. Pasal 33 UUD Tahun 1945 semakin memperkuat bahwa koperasi sebagai salah satu pilar yang mampu mendukung dan mendorong perkembangan ekonomi nasional, di mana dalam Pasal 33 ayat 1 UUD Tahun 1945 
dinyatakan bahwa perekonomian disusun sebagai usaha bersama berdasarkan atas asas kekeluargaan. Hal ini sama dengan asas koperasi, yaitu asas kekeluargaan. Asas kekeluargaan ini mencerminkan bahwa selalu adanya kesadaran dalam hati nurani setiap manusia bekerja sama dan mencapai tujuan pribadi serta tujuan organisasi dalam koperasi.

Koperasi sebagai bagian dari perekonomian suatu negara tentunya memiliki peran yang begitu strategis dalam meningkatkan potensi-potensi ekonomi kerakyatan. Koperasi di Indonesia mampu menjadi kekuatan ekonomi sehingga mampu menopang perekonomian nasional yang seiring berjalannya waktu berkembang dengan cukup pesat. Oleh karena itu, koperasi memiliki sebutan sebagai soko guru perekonomian di Indonesia.

Perkembangan koperasi di Jawa Barat diikuti pula dengan perkembangan koperasi di berbagai daerah, khususnya di Kabupaten Subang yang jumlah koperasinya semakin meningkat, akan tetapi perkembangan koperasi yang semakin meningkat tidak diikuti dengan peningkatan koperasi yang melakukan salah satu kewajibannya, yaitu rapat anggota tahunan (RAT). Berikut adalah data koperasi yang sudah melaksankan rapat anggota tahunan (RAT) yang disajikan dalam bentuk Tabel Keragaan koperasi Kabupaten Subang dari Tahun 2014-2017.

Tabel 1. Keragaan Koperasi Kabupaten Subang Tahun 2014-2017

\begin{tabular}{|l|l|c|ccc|c|}
\hline \multirow{2}{*}{ No } & \multirow{2}{*}{ Keterangan } & \multirow{2}{*}{ Satuan } & \multicolumn{4}{|c|}{ Jumlah (Per Tahun) } \\
\cline { 4 - 7 } & & & 2014 & 2015 & 2016 & 2017 \\
\hline 1 & Jumlah Koperasi & Unit & 154 & 153 & 148 & 143 \\
\hline 2 & Jumlah Anggota & Orang & 38173 & 38143 & 30760 & 21756 \\
\hline 3 & Jumlah Modal Sendiri & $\mathrm{Rp}$ & 164.027 .107 .344 & 164.027 .107 .344 & 165.736 .689 .205 & 169.634 .977 .081 \\
\hline 4 & Jumlah Modal Luar & $\mathrm{Rp}$ & 30.238 .979 .846 & 26.447 .370 .975 & 9.235 .392 .364 & 10.688 .199 .125 \\
\hline 5 & Jumlah Volume Usaha & $\mathrm{Rp}$ & 218.918 .151 .329 & 218.918 .151 .329 & 218.065 .065 .420 & 208.357 .588 .920 \\
\hline 6 & Jumlah Asset & $\mathrm{Rp}$ & 245.561 .962 .525 & 246.561 .962 .525 & 245.330 .062 .197 & 238.684 .137 .425 \\
\hline 7 & Jumlah SHU & $\mathrm{Rp}$ & 17.322 .548 .311 & 17.322 .548 .311 & 36.430 .659 .559 & 33.876 .751 .718 \\
\hline
\end{tabular}

Sumber: Diskoperindag Kabupaten Subang, 2018.

Tabel 1 menunjukkan perkembangan jumlah koperasi dan anggota koperasi di Kabupaten Subang mengalami penurunan. Hal ini terjadi karena menurunnya jumlah koperasi yang melakukan RAT dan anggota koperasi yang semakin berkurang, sehingga berdampak pada jumlah modal sendiri, modal luar, dan volume usaha yang mengalami fluktuatif, sedangkan Sisa Hasil Usaha (SHU) mengalami penurunan dari tahun 2016 ke tahun 2017, yang menandakan bahwa keberhasilan usaha belum mampu tercapai secara optimal. Berdasarkan hasil wawancara dengan Kepala Divisi Koperasi Diskoperindag Kabupaten Subang, bahwa pertambahan jumlah koperasi yang diikuti pula dengan pertambahan koperasi non aktif disebabkan oleh permasalahan yang terjadi pada koperasi di Kabupaten Subang, yaitu para pengurus koperasi dan anggotanya belum mampu melakukan manajemen keanggotaan dengan baik sehingga kemampuan mengelola koperasi pun belum maksimal. Selain itu, partisipasi anggota yang hanya dilakukan diawal pada saat dibentuknya koperasi membuat perkembangan koperasi terhambat, khususnya dalam bidang permodalan.

Hal tersebut terjadi pada kondisi koperasi di Kabupaten Subang yang mengalami penurunan jumlah koperasi dalam memenuhi kewajibannya yaitu rapat anggota tahunan (RAT), ada tiga jenis koperasi yang mengalami penurunan jumlah dalam melaksanakan RAT yaitu KPRI, KSP, dan Koperasi Wanita dengan jumlah terbanyak yaitu tiga koperasi, sedangkan sisanya ada dalam kondisi tetap. Hal ini 
disebabkan ketiga koperasi wanita tersebut tidak terdaftar atau tidak memberikan laporan hasil RAT kepada Diskoperindag Kabupaten Subang. Koperasi wanita yaitu suatu koperasi yang memiliki eksistensi cukup signifikan walaupun belum banyak koperasi wanita yang berskala besar, akan tetapi koperasi wanita dapat membantu pemerintah mengatasi masalah, khususnya dalam peningkatan kualitas pendidikan dan meminimalisir permasalahan gender. Begitupun dengan Kabupaten Subang yang koperasi wanitanya mampu membantu mengatasi permasalahan gender, dan mampu mendapatkan suntikan dana yang cukup besar dari pemerintah. Akan tetapi, perkembangan koperasi wanita di Kabupaten
Subang yang melaksanakan RAT mengalami penurunan, dari 10 koperasi di tahun 2016 menjadi 7 koperasi di tahun 2017. Hal ini menandakan bahwa keberhasilan usaha koperasi mengalami penurunan.

Menurut Ropke (2003:170), faktorfaktor yang mempengaruhi keberhasilan usaha suatu koperasi adalah manajemen keanggotaan (pengelolaan), pelayanan, partisipasi anggota, permodalan dalam koperasi, pembinaan pemerintah, dan kompetensi manajer. Penurunan yang terjadi pun berdampak pada menurunnya nilai keragaan pada koperasi wanita di Kabupaten Subang yang cukup signifikan.

Tabel 2. Data Keragaan Koperasi Wanita

di Kabupaten Subang Tahun 2016-2017

\begin{tabular}{|l|l|c|c|c|}
\hline \multirow{2}{*}{ No } & \multirow{2}{*}{ Keterangan } & \multirow{2}{*}{ Satuan } & \multicolumn{2}{|c|}{ Jumlah (Per Tahun) } \\
\cline { 4 - 6 } & & & 2016 & 2017 \\
\hline 1 & Jumlah Koperasi & Unit & 10 & 7 \\
\hline 2 & Jumlah Anggota & Orang & 5703 & 5023 \\
\hline 3 & Jumlah Modal Sendiri & Rp & 5.975 .085 .984 & 4.190 .977 .961 \\
\hline 4 & Jumlah Modal Luar & Rp & 2.385 .474 .286 & 2.039 .869 .286 \\
\hline 5 & Jumlah Volume Usaha & Rp & 9.512 .845 .234 & 8.519 .998 .234 \\
\hline 6 & Jumlah Asset & Rp & 6.161 .728 .551 & 5.367 .761 .200 \\
\hline 7 & Jumlah SHU & Rp & 838.845 .210 & 789.007 .416 \\
\hline
\end{tabular}

Sumber: Data Koperasi Wanita Kab. Subang (diolah), 2018.

Berdasakan Tabel 2 menunjukkan perkembangan koperasi wanita di Kabupaten Subang yang mengalami penurunan dari tahun 2016 ke tahun 2017. Hal ini terjadi diindikasikan karena menurunnya motivasi anggota dalam keinginan melaksanakan setiap kegiatan koperasi ditandai dengan menurunnya jumlah koperasi yang melaksanakan RAT.

Menurunnya jumlah anggota koperasi menandakan bahwa koperasi belum mampu secara maksimal melakukan proses manajemen keanggotaan sesuai dengan tujuan yang sudah ditentukan. Partisipasi anggota pun menurun ditandai dengan menurunya jumlah modal sendiri yang berdampak pada menurunnya jumlah volume usaha, jumlah aset koperasi, dan jumlah
SHU yang didapatkan oleh koperasi, sehingga begitu penting untuk mengetahui dan memahami motivasi anggota, manajemen keanggotaan, dan partisipasi anggota yang dapat mendukung keberhasilan usaha.

Agar penelitian dan penulisan lebih terfokus dan permasalahan yang diteliti tidak terlalu luas, maka perlu dilakukan batasan masalah. Adapun batasan masalah pada penelitian ini adalah koperasi aktif yang terdaftar di Dinas Koperasi, UKM, Perindustrian, dan Perdagangan (Diskoperindag) di Kabupaten Subang yang sudah melakukan (RAT) dan menyerahkan laporan RAT tersebut ke Diskoperindag pada tahun 2017. Sedangkan yang dimaksud anggota disini adalah anggota koperasi yang 
memiliki jabatan sebagai pengelola dan pengurus koperasi, pernah menjabat sebagai pengelola dan pengurus koperasi serta telah bergabung menjadi anggota minimal 5 (lima) tahun.

Penulis melakukan penelitian pada jenis koperasi wanita, yang dipilih karena koperasi wanita menjadi koperasi yang paling banyak tidak melaksanakan RAT pada tahun 2017.

\section{MATERI DAN METODE}

\section{Manajemen Sumber Daya Manusia}

Hasibuan (2010:10) menjelaskan bahwa Manajemen Sumber Daya Manusia (MSDM) yaitu perencanaan, pengorganisasian, pengarahan, serta pengawasan kegiatan yang berhubungan dengan pengadaan, pengembangan, pemberian kompensasi, pengintegrasian, pemeliharaan, dan pelepasan sumber daya manusia guna tercapainya berbagai tujuan individu, organisasi, dan masyarakat.

\section{Motivasi}

$$
\text { Menurut Sutrisno }
$$

(2009:146) menyatakan bahwa motivasi adalah sesuatu yang bisa mendorong seseorang untuk melaksanakan suatu kegiatan tertentu, oleh sebab itu motivasi sangat sering diterjemahkan sebagai faktor yang mendorong seseorang untuk berperilaku. Indikator-indikator yang digunakan adalah, usaha yang positif dari anggota koperasi dalam kegiatan berkoperasi, kemauan yang kuat untuk untuk turut serta dalam kegiatan koperasi, serta arah dan tujuan yang tentunya ingin diwujudkan dalam mengikuti kegiatan koperasi.

\section{Manajemen Kenggotaan}

Menurut Sutrisno menyatakan bahwa manajemen keanggotaan memiliki pengertian sebagai suatu perencanaan, pengorganisasian, pengarahan, serta pengawasan atas pengadaan anggota, pengembangan, kompensasi, pengintegrasian, pemeliharaan, dan pemutusan hubungan kerja (keanggotaan) dengan maksud untuk mencapai tujuan organisasi secara terpadu. Indikatorindikator yang digunakan adalah, pengadaan, pengembangan, manfaat, pemeliharaan, dan pemutusan hubungan keanggotaan.

\section{Partisipasi Anggota}

Menurut Hendar (2010:166) partisipasi memiliki peranan penting yang mampu menentukan dalam perkembangan koperasi, tanpa partisipasi anggota koperasi tidak mampu berjalan dengan efektif dan efisien. Koperasi dapat berhasil dalam persaingan (bersaing dengan perusahaan nonkoperasi) tetapi tidak akan ada artinya bila anggota tidak memaksimalkan potensi yang dimiliki oleh koperasi. Indikatorindikator yang digunakan untuk variabel partisipasi anggota adalah, partisipasi anggota dalam pengambilan keputusan rapat anggota, partisipasi dalam kontribusi keuangan (modal), partisipasi dalam memanfaatkan pelayanan koperasi, dan partisipasi dalam pengawasan kegiatan koperasi.

\section{Keberhasilan Usaha}

Menurut Sitio dan Tamba (2001:137) keberhasilan koperasi secara umum merupakan variabel kinerja koperasi yang digunakan untuk mengukur perkembangan atau pertumbuhan koperasi di Indonesia yang terdiri dari kelembagaan (jumlah koperasi aktif dan non aktif per wilayah). Indikator-indikator yang digunakan adalah, business succes, member success, dan development succes.

\section{Koperasi Wanita}

Menurut Pratama dalam Devanty dan Saskara (2017:654) koperasi wanita pada awalnya berdiri dengan tujuan untuk dapat memenuhi kebutuhan hidup kaum wanita dan menjadi wadah untuk memberdayakan wanita. Menurut Koutsou (2003:47-57) 
Koperasi wanita adalah jenis koperasi yang bergerak dalam hal perencanaan, organisasi, dan manajemen yang bertujuan untuk menambah pendapatan keluarga dan meningkatkan kondisi status sosial mereka.

\section{Pengaruh Motivasi Anggota, Manajemen Keanggotaan, dan Partisipasi Anggota Terhadap Keberhasilan Usaha}

Keberhasilan koperasi dalam mencapai tujuannya sangat ditentukan oleh beberapa hal di antaranya adalah motivasi anggota, manajemen keanggotaan, dan partisipasi anggota. Ketiga faktor tersebut adalah faktor yang begitu penting karena dalam menjalankan tugasnya guna mencapai tujuan organisasi, koperasi memerlukan kontribusi dari setiap anggota. Hal ini diungkapkan oleh Ropke (2003:170) yaitu ada faktor-faktor yang akan mempengaruhi keberhasilan usaha koperasi di antaranya adalah manajemen keanggotaan (pengelolaan), pelayanan, patisipasi anggota, permodalan dalam koperasi, pembinaan pemerintah, dan motivasi dari setiap anggota dalam rangka pencapaian tujuan. Selain itu, teori ini diperkuat dengan penelitian yang telah dilaksanakan oleh Goncalves (2015) yang menyatakan bahwa kompetensi manajer, manajemen keanggotaan, dan partisipasi anggota memiliki pengaruh secara positif dan signifikan pada kinerja koperasi di Timor Leste.

$\mathrm{H}_{1}$ : Motivasi anggota, manajemen keanggotaan, dan partisipasi anggota secara bersama berpengaruh positif dan signifikan pada keberhasilan usaha.

Pengaruh Motivasi Anggota Terhadap Keberhasilan Usaha

Motivasi dari setiap anggota merupakan suatu faktor yang mampu mendukung suatu organisasi mencapai tujuannya, yaitu untuk mencapai tujuan dan keberhasilan organisasi. Pernyataan tersebut didukung oleh Amir (2017:76) menyatakan bahwa untuk menjamin para karyawan/anggota koperasi mengerjakan apa yang menjadi tugas dan tanggung jawabnya, para manajer atau pimpinan perusahaan perlu memberikan motivasi yang mampu mendorong karyawan atau anggota melakukan apa yang seharusnya dilakukan. Hipotesis ini didukung penelitian yang telah dilaksanakan oleh Ie dan Visantia (2013) yang menyatakan bahwa efikasi diri dan motivasi berpengaruh secara simultan dan parsial pada keberhasilan usaha pada pemilik toko pakaian di Pusat Grosir Metro Tanah Abang Jakarta.

$\mathrm{H}_{2}$ : Motivasi anggota berpengaruh positif dan signifikan terhadap keberhasilan usaha.

\section{Pengaruh Manajemen Keanggotaan Terhadap Keberhasilan Usaha}

Hendar (2010:160) keberhasilan sebuah koperasi sangat ditentukan oleh peran serta anggotanya, oleh karena itu sejak awal berdirinya sebuah koperasi anggota harus mengetahui hak dan kewajiban serta tindakan-tindakan apa yang harus dilaksanakan untuk mendapatkan manfaat berkoperasi, dalam hal ini manajemen keanggotaan memiliki peranan penting karena merupakan proses perencanaan, pengorganisasian, pelaksanaan, dan pengawasan dari pengadaan, pengembangan, pemberian manfaat, pemeliharaan, serta pemutusan hubungan dengan maksud untuk mencapai tujuan yang telah ditentukan bersama. Didukung dengan penelitian yang telah dilaksanakan oleh Ismail (2005) yang menjelaskan bahwa partisipasi anggota dan manajemen keanggotaan memiliki pengaruh secara positif dan signifikan pada keberhasilan usaha.

$\mathrm{H}_{3}$ : Manajemen keanggotaan memiliki pengaruh positif dan signifikan pada keberhasilan usaha koperasi.

\section{Pengaruh Partisipasi Anggota Terhadap Keberhasilan Usaha \\ Menurut Hendar (2010:166)} partisipasi memegang peranan penting yang menentukan perkembangan koperasi. Tanpa partisipasi anggota, koperasi tidak mampu 
berjalan dengan efisien dan efektif. Karena sebab itulah partisipasi dilibatkan dalam tes komparatif koperasi. Koperasi dapat berhasil dalam persaingan (bersaing dengan perusahaan nonkoperasi), tetapi tidak akan ada artinya bila anggota tidak memanfaatkan keunggulan tersebut. Anggota harus berapartisipasi dalam mencapai tujuan bersama. Hipotesis ini didukung penelitian yang telah dilaksanakan oleh Sari (2016) memperlihatkan bahwa partisipasi anggota memiliki pengaruh positif dan signifikan pada keberhasilan usaha secara simultan dan parsial.

$\mathrm{H}_{4}$ : Partisipasi anggota berpengaruh positif dan signifikan terhadap keberhasilan usaha.

\section{Kerangka Pemikiran}

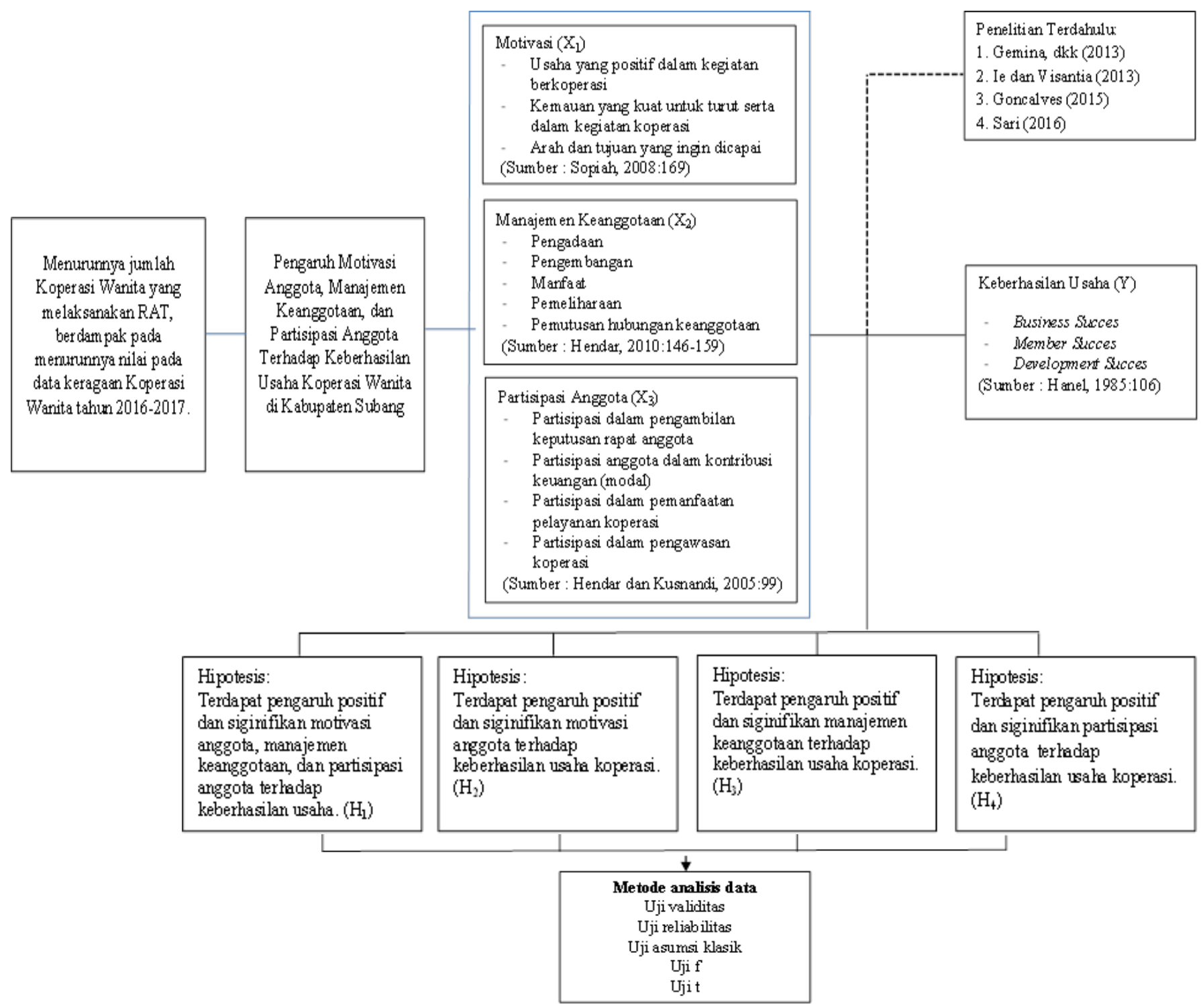

Gambar 1. Kerangka Pemikiran 


\section{Desain Penelitian}

Jenis penelitian yang digunakan dalam penelitian ini adalah penelitian kuantitatif (penelitian kualitatif yang di kuantitatifkan), dengan metode penelitian deskriptif dan verifikatif. Menurut Sugiyono (2013:147) dekriptif merupakan penelitian yang berkaitan dengan pertanyaan terhadap keberadaan variable bebas, baik satu variabel maupun lebih. Sedangkan menurut Sugiyono (2013:147) pengertian verifikatif adalah penelitian yang dilaksanakan pada populasi atau sampel tertentu dengan bertujuan untuk menguji hipotesis yang sudah ditentukan.

Tabel 3. Operasionalisasi Variabel

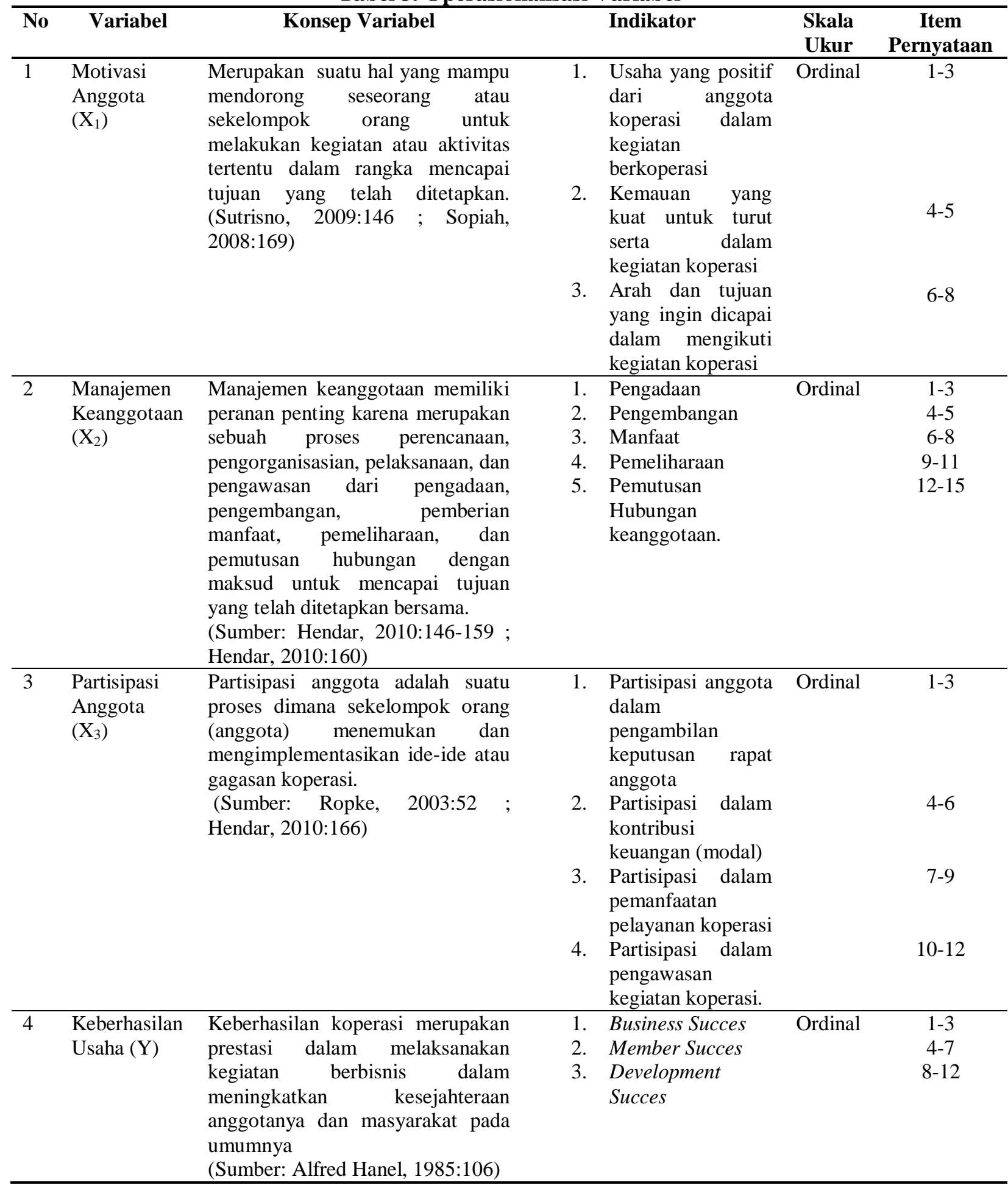




\section{Populasi dan Sampel Penelitian}

Populasi dan sampel dalam penelitian ini adalah anggota Koperasi Wanita di Kabupaten Subang. Teknik pengambilan sampel menggunakan teknik atau pendekatan probability sampling dengan metode proporsional random sampling, dikarenakan jumlah populasi sudah diketahui, maka dapat diambil 100 orang untuk dijadikan sampel (Gay dan Roscoe, 1992:126).

\section{Uji Validitas dan Reliabilitas}

Suatu instrumen dikatakan valid artinya adalah instrumen tersebut bisa digunakan untuk mengukur apa yang seharusnya diukur (Sugiyono, 2014:203). Uji validitas dalam penelitian ini dilaksanakan pada 30 responden dengan hasil rekapitulasi berikut ini:

Tabel 4. Rekapitulasi Hasil Uji Validitas

\begin{tabular}{|c|c|c|c|c|}
\hline No & Variabel & Indikator & $\begin{array}{c}\text { Item } \\
\text { Pernyataan }\end{array}$ & $\begin{array}{l}\text { Jumlah Item } \\
\text { Sesudah Uji } \\
\text { Validitas }\end{array}$ \\
\hline \multirow[t]{3}{*}{1} & $\left(\mathrm{X}_{1}\right)$ & $\begin{array}{l}\text { 1. Usaha yang positif dari anggota } \\
\text { koperasi dalam kegiatan } \\
\text { berkoperasi }\end{array}$ & $1-3$ & 3 \\
\hline & & $\begin{array}{l}\text { 2. Kemauan yang kuat untuk turut } \\
\text { serta dalam kegiatan koperasi }\end{array}$ & $4-5$ & 2 \\
\hline & & $\begin{array}{l}\text { 3. Arah dan tujuan yang ingin } \\
\text { dicapai dalam mengikuti } \\
\text { kegiatan koperasi }\end{array}$ & $6-8$ & 3 \\
\hline \multirow[t]{5}{*}{2} & $\left(\mathrm{X}_{2}\right)$ & 1. Pengadaan & $1-3$ & 2 \\
\hline & & 2. Pengembangan & $4-5$ & 1 \\
\hline & & 3. Manfaat & $6-8$ & 3 \\
\hline & & 4. Pemeliharaan & $9-11$ & 2 \\
\hline & & $\begin{array}{ll}\text { 5. Pemutusan } \\
\text { keanggotaan. }\end{array}$ & $12-15$ & 3 \\
\hline \multirow[t]{4}{*}{3} & $\left(\mathrm{X}_{3}\right)$ & $\begin{array}{l}\text { 1. Partisipasi anggota } \\
\text { pengambilan } \\
\text { anggota }\end{array}$ & $1-3$ & 3 \\
\hline & & $\begin{array}{l}\text { 2. Partisipasi dalam kontribusi } \\
\text { keuangan (modal) }\end{array}$ & $4-6$ & 2 \\
\hline & & $\begin{array}{llr}\text { 3. } & \text { Partisipasi } & \text { dalam } \\
\text { memanfaatkan } & \text { pelayanan }\end{array}$ & $7-9$ & 2 \\
\hline & & $\begin{array}{l}\text { koperasi } \\
\text { 4. Partisipasi dalam pengawasan } \\
\text { kegiatan koperasi. }\end{array}$ & $10-12$ & 3 \\
\hline \multirow[t]{4}{*}{4} & $(\mathrm{Y})$ & 1. Business Succes & $1-3$ & 2 \\
\hline & & 2. Member Succes & $4-7$ & 3 \\
\hline & & 3. Development Succes & $8-12$ & 5 \\
\hline & Jumlah & & 47 & 39 \\
\hline
\end{tabular}

Instrumen yang reliabel adalah instrumen yang jika dipakai beberapa kali untuk mengukur objek yang sama akan mendapatkan data yang sama (Sugiyono, 2014:203). Hasil uji reliabilitas dengan teknik Alpha Cronbach memperlihatkan bahwa semua variabel penelitian yang terdiri dari motivasi anggota, manajemen keanggotaan, dan partisipasi anggota serta keberhasilan usaha dinyatakan reliabel karena memiliki nilai Alpha Cronbach lebih besar dari 0,6.

\section{Uji Asumsi Klasik}

Uji asumsi klasik dalam penelitian ini diantaranya adalah uji normalitas, uji heteroskedastisitas, dan uji multikolinearitas. Hasil uji normalitas dengan menggunakan 
uji Kolmogorov-Smirnov menunjukkan nilai signifikansi lebih besar dari 0,05 jadi bisa dikatakan bahwa model regresi memiliki distribusi data normal. Hasil uji heteroskedastisitas dengan menggunakan scatterplot diketahui bahwa pencaran data tidak menunjukan pola tertentu dan menyebar secara acak, diatas dan dibawah angka nol pada sumbu Y, disimpulkan bahwa tidak adanya masalah heteroskedastisitas pada data penelitian. Hasil uji multikolinearitas dengan menggunakan uji nilai Tolerance dan VIF menunjukkan nilai tolerance dari setiap variabel memiliki nilai lebih tinggi dari nilai cutoff atau tolerance $(0,05)$ dan nilai VIF lebih kecil dari 5. Hal ini menunjukkan bahwa variable-variable bebas dalam model regresi tersebut tidak mengalami multikolinearitas.

\section{Metode Analisis Data}

Data yang terkumpul dianalisis dengan cara deskriptif dan verifikatif dengan menggunakan uji statistik. Untuk melihat ada atau tidaknya pengaruh antara motivasi anggota, Manajemen keanggotaan, dan partisipasi anggota pada keberhasilan usaha, maka digunakan rumus sebagai berikut:

$$
\mathbf{Y}=\mathbf{a}+\boldsymbol{\beta}_{1} \mathbf{X}_{1}+\boldsymbol{\beta}_{2} \mathbf{X}_{2}+\boldsymbol{\beta}_{3} \mathbf{X}_{3}+\mathcal{E}
$$

Keterangan:

$\mathrm{Y}=$ Variabel terikat (Keberhasilan usaha)

$\mathrm{Xi}=$ Variabel bebas

$\mathrm{a} \quad=$ Bilangan konstanta

$\beta_{1}=$ Koefisien regresi untuk melihat sampai mana pengaruh motivasi anggota terhadap keberhasilan usaha.

$\beta_{2}=$ Koefisien regresi untuk melihat sampai mana pengaruh manajemen keanggotaan terhadap keberhasilan usaha.

$\beta_{3}=$ Koefisien regresi untuk melihat sampai mana pengaruh partisipasi anggota terhadap keberhasilan usaha.

$\varepsilon \quad=$ Faktor lain yang tidak dimasukan dalam penelitian

$\mathrm{i}=$ Motivasi anggota $\left(\mathrm{X}_{1}\right)$, manajemen keanggotaan $\left(\mathrm{X}_{2}\right)$, partisipasi anggota $\left(\mathrm{X}_{3}\right)$

Koefisien korelasi (R) mengukur kekuatan dan arah hubungan secara linier dari dua variabel yang diteliti. koefisien korelasi hanya mengukur kekuatan hubungan linier dan tidak pada hubungan non linier (Yuliardi dan Nuraeni, 2017:172)

Tabel 5. Interpretasi Koefisien Korelasi

\begin{tabular}{cc}
\hline Interval Koefisien & Tingkat Hubungan \\
\hline $0,00-0,199$ & Sangat Rendah \\
$0,20-0,399$ & Rendah \\
$0,40-0,599$ & Sedang \\
$0,60-0,799$ & Kuat \\
$0,80-1,000$ & Sangat Kuat \\
\hline
\end{tabular}

Sumber: Sugiyono, 2014:286 Metode Penelitian Manajemen

Sedangkan untuk melihat kontribusi pengaruh motivasi anggota $\left(\mathrm{X}_{1}\right)$, manajemen keanggotaan $\left(\mathrm{X}_{2}\right)$, dan partisipasi anggota $\left(\mathrm{X}_{3}\right)$ terhadap keberhasilan usaha $(\mathrm{Y})$. maka, digunakan koefisien determinasi $\left(\mathrm{R}^{2}\right)$ dengan rumus yaitu:

$\begin{array}{lll} & \text { KD }=\boldsymbol{r}^{\mathbf{2}} \mathbf{x} \mathbf{1 0 0 \%} \\ \text { Keterangan: } & \mathrm{KD} \quad=\text { Koefisien } \\ \text { Determinasi } & \\ & r \quad=\text { Koefisien Korelasi }\end{array}$

\section{Pengujian Hipotesis}

Uji statistik $F$ dipakai untuk mengukur apakah variabel independen yang dimaksud dalam model memiliki pengaruh secara bersama-sama (simultan) terhadap variabel dependen. Dengan level signifikansi yang ditetapkan adalah 5\%. Uji statistik $\mathrm{t}$ digunakan untuk mengukur apakah variabel independen yang dimasukkan kedalam model penelitian memiliki pengaruh secara individual (parsial) terhadap variabel dependen dengan memakai tingkat signifikansi $5 \%$. 


\section{HASIL DAN PEMBAHASAN}

\section{Karakteristik Anggota Koperasi}

Mayoritas anggota koperasi adalah wanita dengan jumlah 93 orang atau sebesar 93\%, dimana usia anggota dan pengurus sebagian besar adalah > 40 tahun dengan jumlah 46 orang atau sebesar $46 \%$, dengan pendidikan terakhir dari sebagian besar anggota adalah SD dengan jumlah 48 orang atau sebesar $48 \%$, dan sebagian besar memiliki jabatan sebagai pengurus/pengelola (BPH) koperasi dengan jumlah 55 orang atau sebesar 55\%. Sedangkan penghasilan perbulan dari sebagian besar anggota dan pengurus adalah Rp1,1-Rp2,5 juta perbulan dengan jumlah 41 orang atau sebesar $41 \%$, serta sebagian besar anggota dan pengurus telah memiliki status pernikahan sebanyak 99 orang atau sebesar $99 \%$.

\section{Rekapitulasi Penilaian Anggota Koperasi terhadap Motivasi Anggota}

Adapun rekapitulasi tanggapan anggota koperasi terhadap motivasi anggota koperasi di Kabupaten Subang, sebagai berikut:

Tabel 6. Rekapitulasi Penilaian Anggota Koperasi Terhadap Motivasi Anggota $\left(\mathbf{X}_{1}\right)$

\begin{tabular}{clcc}
\hline No & \multicolumn{1}{c}{ Uraian } & $\begin{array}{c}\text { Penilaian } \\
\text { Anggota } \\
\text { Koperasi }\end{array}$ & Keterangan \\
\hline 1 & Berbelanja barang dan jasa pada koperasi & 4,22 & Sangat Baik \\
2 & Memberikan kritik dan saran dalam pengelolaan koperasi & 4,22 & Sangat Baik \\
3 & Mampu mengajak orang lain untuk bergabung dalam koperasi & 4,38 & Sangat Baik \\
4 & Ikut berpartisipasi dalam kegiatan koperasi & 4,26 & Sangat Baik \\
5 & Ikut serta dalam penentuan strategi koperasi & 3,91 & Baik \\
6 & Koperasi membantu memenuhi kebutuhan anggota & 4,28 & Sangat Baik \\
7 & Mendapat SHU sesuai dengan kontribusi yang diberikan & 4,23 & Sangat Baik \\
8 & Pengalaman bertambah dengan menjadi anggota & 4,25 & Sangat Baik \\
\hline & Rata-rata penilaian responden terhadap motivasi anggota $\left(\mathrm{X}_{1}\right)$ & 4,22 & Sangat Baik \\
\hline
\end{tabular}

Penilaian anggota koperasi terhadap koperasi dapat berkembang dalam motivasi anggota adalah sebesar 4,22 yang menjalankan setiap kegiatannya.

masuk ke dalam kriteria sangat baik. Rekapitulasi Penilaian Anggota Koperasi Artinya, anggota koperasi sudah memiliki motivasi yang sangat baik dalam melaksanakan setiap kegiatannya yang berhubungan dengan koperasi, sehingga terhadap Manajemen Keanggotaan

Adapun rekapitulasi tanggapan anggota koperasi terhadap manajemen keanggotaan koperasi di Kabupaten Subang, sebagai berikut:

Tabel 7. Rekapitulasi Penilaian Anggota Koperasi Terhadap Manajemen Keanggotaan $\left(X_{2}\right)$

\begin{tabular}{clcc}
\hline No & \multicolumn{1}{c}{ Uraian } & $\begin{array}{c}\text { Penilaian } \\
\text { Anggota } \\
\text { Koperasi }\end{array}$ & Keterangan \\
\hline 1 & Menerapkan manajemen keanggotaan dengan baik & 4,54 & Sangat Baik \\
2 & Penempatan anggota sesuai tugas dan tanggung jawab & 4,39 & Sangat Baik \\
3 & Pelatihan anggota tentang koperasi & 4,47 & Sangat Baik \\
4 & Balas jasa yang layak & 4,5 & Sangat Baik \\
5 & Pelayanan untuk memotivasi anggota & 4,52 & Sangat Baik \\
6 & Menghargai anggota & 4,6 & Sangat Baik \\
7 & Jaminan asuransi & 3,44 & Baik \\
8 & Jaminan kesehatan & 3,42 & Baik \\
9 & Pemberhentian anggota apabila berbuat curang & 3,95 & Baik \\
10 & Sebelum menjadi anggota mendapat penyuluhan tentang & 3,17 & Cukup Baik \\
& koperasi & & Baik \\
\hline 11 & Pemberhentian anggota dengan cara yang baik dan sesuai & 4,19 & Baik
\end{tabular}

$\left(\mathrm{X}_{2}\right)$ 
Penilaian anggota koperasi terhadap manajemen keanggotaan adalah sebesar 4,11 yang masuk ke dalam kriteria baik. Artinya, manajemen keanggotaan yang telah dilaksanakan oleh koperasi sudah berjalan dengan baik ditunjukan dengan koperasi yang mampu menjalankan kegiatannya secara efektif dan efisien.

\section{Rekapitulasi Penilaian Anggota Koperasi terhadap Partisipasi Anggota}

Adapun rekapitulasi tanggapan anggota koperasi terhadap partisipasi anggota koperasi di Kabupaten Subang, sebagai berikut:

Tabel 8. Rekapitulasi Penilaian Anggota Koperasi Terhadap Partisipasi Anggota $\left(\mathbf{X}_{3}\right)$

\begin{tabular}{clcc}
\hline No & \multicolumn{1}{c}{ Uraian } & $\begin{array}{c}\text { Penilaian } \\
\text { Anggota } \\
\text { Koperasi }\end{array}$ & Keterangan \\
& & 4,69 & Sangat Tinggi \\
\hline 1 & Wajib menghadiri RAT & 4,55 & Sangat Tinggi \\
2 & Menyampaikan pendapat dan saran pada RAT & 4,26 & Sangat Tinggi \\
3 & Ikut serta dalam pengambilan keputusan & 4,34 & Sangat Tinggi \\
4 & Membayar simpanan pokok dan simpanan wajib & 4,15 & Tinggi \\
5 & Berpartisipasi baik dalam permodalan & 4,07 & Tinggi \\
6 & Memanfaatkan fasilitas dan membeli kebutuhan pada & 4,10 & Tinggi \\
7 & koperasi & 4,13 & Tinggi \\
8 & Memanfaatkan pelayanan unit usaha & 4 & Tinggi \\
9 & Mengikuti perkembangan usaha & 3,99 & Tinggi \\
10 & Tidak dapat menyampaikan kritik jika tidak sesuai & & Sangat Tinggi \\
& AD/ART
\end{tabular}

Penilaian anggota koperasi terhadap Rekapitulasi Penilaian Anggota Koperasi partisipasi anggota adalah sebesar 4,23 yang masuk kedalam kriteria sangat tinggi. Artinya, secara keseluruhan para anggota koperasi sudah berpartisipasi secara maksimal dalam menunjang setiap kegiatan terhadap Keberhasilan Usaha

Adapun rekapitulasi tanggapan anggota koperasi terhadap motivasi anggota koperasi di Kabupaten Subang, sebagai berikut: koperasi.

Tabel 9. Rekapitulasi Penilaian Anggota Koperasi Terhadap Keberhasilan Usaha (Y)

\begin{tabular}{clcc}
\hline No & \multicolumn{1}{c}{ Uraian } & $\begin{array}{c}\text { Penilaian } \\
\text { Anggota } \\
\text { Koperasi }\end{array}$ & Keterangan \\
\hline 1 & SHU mengalami peningkatan & 4,86 & Sangat Tinggi \\
2 & Mengalami peningkatan usaha & 4,68 & Sangat Tinggi \\
3 & Bonus bagi anggota berprestasi & 4,09 & Tinggi \\
4 & Memberikan SHU pada setiap anggota & 4,68 & Sangat Tinggi \\
5 & Koperasi memberikan tunjangan kesejahteraan & 3,89 & Tinggi \\
6 & Tunjangan kesehatan & 3,81 & Tinggi \\
7 & Mempekerjakan no nanggota secara proporsional & 3,12 & Cukup Tinggi \\
8 & Menyediakan kebutuhan pokok & 3,98 & Tinggi \\
9 & Alokasi dana sosial dari SHU & 4,47 & Sangat Tinggi \\
10 & Kontribusi pada pengusaha kecil & 4,20 & Sangat Tinggi \\
\hline \multicolumn{2}{l}{ Rata-rata penilaian responden terhadap keberhasilan usaha (Y) } & 4,18 & Tinggi \\
\hline
\end{tabular}

Penilaian anggota koperasi terhadap koperasi sudah mampu mencapai tujuan dan keberhasilan usaha adalah sebesar 4,18 yang rencana yang ditentukan secara maksimal masuk kedalam kriteria tinggi. Artinya, dan secara keseluruhan sudah terpenuhi.

\section{Hasil Analisis Regresi Linear Berganda \\ Berdasarkan perhitungan analisis regresi linear berganda dengan $Y=\mathbf{2 , 7 8 3}+\mathbf{0 , 2 9 2} X_{1}+\mathbf{0 , 4 8 9} X_{2}+\mathbf{0 , 2 9 8} X_{3}+\varepsilon$}


Berdasarkan persamaan tersebut dapat diketahui bahwa motivasi anggota, manajemen keanggotaan, dan partisipasi anggota memiliki pengaruh positif terhadap keberhasilan usaha. Adapun hubungan antara $\mathrm{X}_{1}, \mathrm{X}_{2}$, dan $\mathrm{X}_{3}$ terhadap $\mathrm{Y}$ menunjukkan angka korelasi (R) sebesar 0,772 artinya hubungan variabel independen dengan variabel dependen termasuk kategori kuat. Semakin tinggi pengaruh motivasi anggota, manajemen keanggotan, dan partisipasi anggota maka keberhasilan usaha akan semakin tinggi. Selain itu, diketahui juga nilai R Squrare adalah sebesar 0,596 atau $59,6 \%$, artinya persentase sumbangan dari variabel motivasi anggota $\left(\mathrm{X}_{1}\right)$, manajemen keanggotaan $\left(\mathrm{X}_{2}\right)$, dan partisipasi anggota $\left(\mathrm{X}_{3}\right)$ terhadap keberhasilan usaha $(\mathrm{Y})$ adalah sebesar 59,6\%, sedangkan sisanya sebesar $40,4 \%$ dipengaruhi oleh variable -variable lain yang tidak dimasukan dalam penelitian. Hal ini sesuai dengan teori yang disampaikan oleh Ropke (2003:170) yang menyatakan bahwa keberhasilan usaha suatu koperasi juga dipengaruhi oleh pelayanan, permodalan dalam koperasi, pembinaan pemerintah, dan kompetensi manajer.

\section{Pengujian Secara Simultan (Uji F)}

Untuk melihat pengaruh motivasi anggota $\left(X_{1}\right)$, manajemen keanggotaan $\left(X_{2}\right)$, dan partisipasi anggota $\left(\mathrm{X}_{3}\right)$ secara simultan terhadap keberhasilan usaha (Y) secara statistik akan di uji hipotesisnya sebagai berikut:

Ho : $\beta \mathrm{i} \leq 0$ : Motivasi anggota, manajemen keanggotaan, dan partisipasi anggota tidak memiliki pengaruh positif dan signifikan secara simultan terhadap keberhasilan usaha.

$\mathrm{Ha}: \beta \mathrm{i}>0$ : Motivasi anggota, manajemen keanggotaan, dan partisipasi anggota memiliki pengaruh positif dan signifikan secara simultan terhadap keberhasilan usaha.

Berdasarkan perhitungan statistik, maka diperoleh nilai $F_{\text {hitung }}$ sebesar 47,221 dan nilai $\mathrm{F}_{\text {tabel }}$ untuk $\alpha=0,05$ dengan derajat kebebasan $\mathrm{V}_{1}=4-1=3$ dan $\mathrm{V}_{2}=100-3$ $1=96$ adalah sebesar 2,70 dimana hal ini memperlihatkan bahwa $F_{\text {hitung }}$ lebih besar dari $\mathrm{F}_{\text {tabel }}(47,221>2,70)$. Dengan demikian maka bisa disimpulkan bahwa $\mathrm{H}_{0}$ ditolak dan Ha diterima, artinya dengan tingkat kepercayaan $95 \%$ variabel bebas yaitu motivasi anggota, manajemen keanggotaan, dan partisipasi anggota memiliki pengaruh positif dan signifikan secara bersama-sama (simultan) terhadap keberhasilan usaha. Hal ini juga didukung penelitian yang dilakukan oleh Ismail (2007) yang menyatakan bahwa partisipasi anggota dan manajemen keanggotaan memiliki pengaruh positif dan signifikan pada keberhasilan usaha.

\section{Pengujian Regresi Secara Parsial (Uji t)}

Berdasarkan perhitungan statisitik maka dapat terlihat nilai thitung dan nilai signifikansi dari masing-masing variabel independen. Sedangkan nilai $t_{\text {tabel }}$ untuk $\alpha=$ 0,05 dengan derajat kebebasan $100-3-1=$ 96 yaitu sebesar 1,984. Dengan demikian maka diperoleh hasil sebagai berikut:

\section{Pengaruh motivasi anggota $\left(\mathrm{X}_{1}\right)$} terhadap keberhasilan usaha (Y)

Untuk melihat pengaruh motivasi anggota $\left(\mathrm{X}_{1}\right)$ terhadap keberhasilan usaha (Y) secara statistik akan di uji hipotesisnya sebagai berikut:

$\mathrm{Ho}_{1}: \beta_{1} \leq 0$ : motivasi anggota tidak mempunyai pengaruh positif dan signifikan pada keberhasilan usaha koperasi.

$\begin{aligned} \mathrm{Ha}_{1}: \beta_{1}>0: & \text { motivasi anggota } \\ & \text { mempunyai pengaruh } \\ & \text { positif dan signifikan } \\ & \text { pada keberhasilan usaha } \\ & \text { koperasi. }\end{aligned}$

Motivasi anggota $\left(\mathrm{X}_{1}\right)$ dengan nilai thitung sebesar 2,637 lebih besar dari nilai $t_{\text {tabel }}$ $(2,637>1,984)$ dan nilai signifikansi sebesar 0,001 lebih kecil dari 0,05 $(0,001<0,05)$. Dengan demikian maka Ha diterima dan Ho ditolak, artinya secara parsial motivasi anggota 
mempunyai pengaruh positif dan signifikan pada keberhasilan usaha koperasi. Hasil tersebut telah didukung dengan penelitian yang dilaksanakan oleh Purnama (2011), yang menyatakan bahwa secara masing-masing (parsial) motivasi anggota memiliki pengaruh yang positif dan signifikan pada keberhasilan usaha.

2. Pengaruh manajemen keanggotaan (X) terhadap keberhasilan usaha (Y)

Untuk melihat pengaruh manajemen keanggotaan $\left(\mathrm{X}_{2}\right)$ pada keberhasilan usaha (Y) secara statistik akan di uji hipotesisnya sebagai berikut:

$\mathrm{Ho}_{2}: \beta_{2} \leq 0$ : manajemen keanggotaan tidak mempunyai pengaruh positif dan signifikan pada keberhasilan usaha koperasi.

$\mathrm{Ha}_{2}: \beta_{2}>0$ : manajemen

keanggotaan mempunyai pengaruh positif dan signifikan pada keberhasilan usaha koperasi.

Manajemen keanggotaan $\left(\mathrm{X}_{2}\right)$ dengan nilai $t_{\text {hitung }}$ sebesar 6,261 lebih besar dari nilai $t_{\text {tabel }}(6,261>1,984)$ dan nilai signifikansi sebesar 0,000 lebih kecil dari $0,05 \quad(0,000<0,05)$. Dengan demikian maka Ha diterima dan Ho ditolak, artinya secara parsial manajemen keanggotaan mempunyai pengaruh positif dan signifikan pada keberhasilan usaha koperasi. Hasil tersebut telah didukung penelitian yang dilaksanakan oleh Handayani, dkk (2017) yang menyatakan bahwa manajemen keanggotaan koperasi memiliki pengaruh positif dan signifikan pada keberhasilan usaha.

3. Pengaruh partisipasi anggota $\left(\mathbf{X}_{3}\right)$ terhadap keberhasilan usaha $(Y)$

Untuk melihat pengaruh partisipasi anggota $\left(\mathrm{X}_{3}\right)$ pada keberhasilan usaha (Y) secara statistik akan di uji hipotesisnya sebagai berikut:

$\mathrm{Ho}_{3}: \beta_{3} \leq 0$ : partisipasi anggota tidak mempunyai pengaruh positif dan signifikan pada keberhasilan usaha koperasi.

$\mathrm{Ha}_{3}: \beta_{3}>0$ : partisipasi anggota mempunyai pengaruh positif dan signifikan pada keberhasilan usaha koperasi.

Partisipasi anggota $\left(\mathrm{X}_{3}\right)$ dengan nilai thitung sebesar 3,925 lebih besar dari nilai $t_{\text {tabel }}(3,925>1,984)$ dan nilai signifikansi sebesar 0,000 lebih kecil dari $0,05(0,000<0,05)$. Dengan demikian maka Ha diterima dan Ho ditolak, artinya secara parsial partisipasi anggota mempunyai pengaruh positif dan signifikan pada keberhasilan usaha. Hasil tersebut telah didukung penelitian yang dilaksanakan oleh Sugiastini dan Yuliarmi (2015), yang menyatakan bahwa partisipasi anggota memiliki pengaruh positif dan signifikan secara parsial pada keberhasilan koperasi.

Adapun rekapitulasi hasil pengujian hipotesis secara parsial (Uji t) adalah sebagai berikut:

Tabel 10. Rekapitulasi Pengujian Secara Parsial

\begin{tabular}{clrcc}
\hline No & \multicolumn{1}{c}{ Variabel } & $\begin{array}{c}\text { Nilai } \\
\text { Beta }\end{array}$ & Kontribusi (\%) & Keterangan \\
\hline 1 & Motivasi Anggota $\left(\mathrm{X}_{1}\right)$ & 0,212 & $0,212 \times 0,582=12,33 \%$ & Positif dan signifikan \\
2 & Manajemen Keanggotaan $\left(\mathrm{X}_{2}\right)$ & 0,475 & $0,475 \times 0,674=32,01 \%$ & Positif dan signifikan \\
3 & Partisipasi Anggota $\left(\mathrm{X}_{3}\right)$ & 0,287 & $0,287 \times 0,532=15,26 \%$ & Positif dan signifikan \\
\hline
\end{tabular}


Berdasarkan tabel tersebut ketiga variabel bebas yaitu motivasi anggota $\left(\mathrm{X}_{1}\right)$, manajemen keanggotaan $\left(\mathrm{X}_{2}\right)$, dan partisipasi anggota $\left(\mathrm{X}_{3}\right)$ memiliki pengaruh secara positif dan signifikan pada keberhasilan usaha (Y). Hal ini ditunjukan dengan nilai $t_{\text {hitung }}$ masing-masing variable lebih besar dari nilai $t_{\text {tabel, }}$ menurut Maja dan Sudibia (2012:56) untuk mengetahui variable bebas mana yang paling memiliki pengaruh digunakan uji Standardized Coefficient Beta. Pengaruh dominan variable independen pada variable dependen dapat dilihat pada Standardized Coefficient Beta yang memiliki nilai tertinggi. Varible manajemen keanggotaan $\left(\mathrm{X}_{2}\right)$ menjadi variable yang berpengaruh paling dominan dibandingkan dengan variable motivasi anggota $\left(\mathrm{X}_{1}\right)$ dan partisipasi anggota $\left(\mathrm{X}_{3}\right)$, hal ini dapat dilihat pada nilai beta yang lebih tinggi yaitu 0,475 dan memiliki kontribusi pengaruh terhadap variabel Y sebesar 32,01\%.

\section{KESIMPULAN DAN IMPLIKASI}

Berdasarkan hasil penelitian, maka dapat disimpulkan:

1. Berdasarkan penilaian anggota koperasi terhadap motivasi anggota, manajemen keanggotaan, partisipasi anggota, dan keberhasilan usaha maka disimpulkan bahwa:

a. Motivasi anggota koperasi sangat baik. Para anggota sudah mampu menyampaikan aspirasi dan mampu menjalankan hak serta tanggungjawabnya secara maksimal.

b. Manajemen keanggotaan yang telah dilaksanakan oleh koperasi baik. Secara keseluruhan koperasi sudah mampu mencapai setiap tujuan yang sudah ditentukan secara efektif dan efisien.

c. Partisipasi yang dilaksanakan oleh anggota koperasi sudah sangat tinggi. Anggota koperasi sudah mampu memahami peranannya dalam mendukung jalannya kegiatan koperasi.

d. Keberhasilan usaha yang mampu dicapai oleh koperasi tinggi. Koperasi secara keseluruhan telah berhasil mencapai tujuan dan program yang telah ditentukan.

2. Pengujian secara bersama-sama (Uji F) menunjukkan bahwa motivasi anggota, manajemen keanggotaan, dan partisipasi anggota secara simultan (bersama-sama) mempunyai pengaruh positif dan signifikan pada keberhasilan usaha koperasi. Hasil pengujian secara parsial (Uji t) adalah motivasi anggota $\left(\mathrm{X}_{1}\right)$, manajemen keanggotaan $\left(\mathrm{X}_{2}\right)$, dan Partisipasi anggota $\left(\mathrm{X}_{3}\right)$ memiliki pengaruh positif dan signifikan pada keberhasilan usaha koperasi (Y).

Adapun saran yang diberikan pada penelitian ini yaitu:

1. Memberikan pelatihan dan pendidikan kepada para anggota, mengikutsertakan anggota pada lembaga-lembaga sertifikasi khususnya dalam hal menentukan sebuah strategi koperasi agar para anggota selalu berusaha ikut berpartisipasi, khususnya dalam penentuan strategi koperasi.

2. Koperasi diusahakan selalu memberikan penyuluhan pada anggota dan calon anggota koperasi, karena hal tersebut akan membantu mempermudah anggota dalam menjalankan setiap tugasnya.

3. Sebaiknya koperasi diusahakan selalu memberikan pengarahan pada anggota, khususnya dalam tata cara penyampaian kritik dan saran pada pengurus atau pengelola koperasi untuk proses perbaikan.

4. Koperasi diusahakan untuk mempekerjakan nonanggota secara proporsional untuk membantu menjalankan kegiatan sesuai dengan kebutuhan yang ada.

5. Pihak koperasi sebaiknya terus memberikan pemahaman pada anggota, tentang pentingnya manfaat tunjangan, khususnya tunjangan kesehatan dan jaminan asuransi yang sangat penting bagi anggota koperasi.

6. Untuk penelitian selanjutnya mengenai manajemen sumber daya manusia dan berkaitan dengan koperasi, maka hendaknya peneliti lain lebih memperdalam mengenai faktor-faktor lain yang mempengaruhi keberhasilan usaha suatu koperasi, seperti pelayanan, permodalan dalam koperasi, pembinaan pemerintah, dan kompetensi manajer.

\section{UCAPAN TERIMA KASIH}

Ucapan terima kasih kepada Koperasi Wanita Subang serta semua pihak yang terkait dalam penelitian ini 


\section{DAFTAR PUSTAKA}

Hanel, Alfred. 1985. Basic Aspect of Coopertaive Organization. Marburg.

Amir, M Amir. 2017. Perilaku Organisasi. Kencana. Jakarta.

Dinas Koperasi dan UMKM Jawa Barat. 2017. Perkembangan jumlah koperasi di Kabupaten Subang. http://www.diskumkm.jabarprov.go.id/mikro sitele-Profile/Koperasi Kab Subang.htm

(diakses pada hari, Selasa 29 Agustus 2017 Pukul 14.51)

Devanty, Cyntia Putri dan Ida Ayu Nyoman Saskara. 2017. Peran Koperasi Wanita dalam Upaya Pemberdayaan Perempuan Pada Koperasi Wanita di Kecamatan Blahbatuh Kabupaten Gianyar, E-Jurnal EP Unud, Vol. 6, No. 4: 472-498. ISSN: 23030178. Universitas Udayana Bali.

Gay, LR dan P.L Diehl 1992, Research Methods for Business Research Methods. Richard D. Irwin, Inc. Boston.

Goncalves, Mendes. 2015. Pengaruh Kompetensi Manajer, Manajemen Keanggotaan, dan Partisipasi Anggota Terhadap Kinerja Koperasi di Timor Leste. Jurnal Ilmiah Manajemen Coopetition Vol. 6 No. 2 (2015). ISSN: 2086-4620. Ikopin Bandung.

Handayani, Rossy, May Maemunah dan Arpizal. 2017. Pengaruh Persepsi Anggota Tentang Manajemen Keanggotaan Koperasi dan Pelayanan Koperasi Terhadap Keberhasilan KUD Sejahtera Sarana Jaya Kecamatan Bathin III Kabupaten Bungo. Skripsi. Univeritas Jambi. (diakses pada hari Kamis, 21 Juni 2018 pukul 10.35).

Hasibuan, SP. Malayu. 2010. Manajemen Sumber Daya Manusia. Bumi Askara. Jakarta

Hendar. 2010. Manajemen Perusahaan Koperasi Pokok-pokok Pikiran Mengenai Manajemen dan Kewirausahaan Koperasi. Erlangga. Jakarta

Ie, Mei dan Eni Visantia. 2013. Pengaruh Efikasi Diri dan Motivasi Terhadap Keberhasilan Usaha Pada Pemilik Toko Pakaian di Pusat Grosir Metro Tanah Abang, Jakarta. Jurnal Manajemen Vol. 13 No. 1 November 2013. Universitas Tarumanegara.

Ismail, Ahmar. 2007. Pengaruh Partisipasi Anggota dan Manajemen Terhadap Keberhasilan Usaha Koperasi Simpan Pinjam di Kota Batam. Tesis. Universitas
Airlangga Surabaya. (diakses pada hari Kamis, 21 Juni 2018 pukul 10.35).

Koutsou, S. 2003. Women's Cooperative in Greece: An On-going Story of Battles, Successes and Problems. Journal of Rural Cooperation, Vol. 31 No. 1: 47-57.

Maja, Onesimus Yulianus dan I Ketut Sudibia. 2012. Analisis Faktor-Faktor yang Mempengaruhi Produktivitas Tenaga Kerja Wanita Sebagai Pengepul Squin Secara Putting Out. E-Jurnal EP Unud. Universitas Udayana Bali. (diakses pada hari Jumat, 22 Juni 2018 pukul 08.35).

Purnama, Chamdan Suyatno. 2011. Motivasi dan Kemampuan Usaha dalam Meningkatkan Keberhasilan Usaha Industri Kecil (Studi Pada Industri Kecil Sepatu di Jawa Timur). Jurnal Manajemen dan Kewirausahaan (JMK) Vol. 12 No. 2: 177-184. ISSN: 14111438. Universitas Kristen Petra.

Ropke, Jochen. 2003. Ekonomi Koperasi Teori dan Manajemen. Salemba Empat. Jakarta

Sari, Ni Made Krisna. 2016. Pengaruh Partisipasi Anggota, Pelayanan, dan Permodalan Terhadap Keberhasilan Usaha Koperasi Dharma Sesana Desa Lebih Kabupaten Gianyar. Jurnal Program Studi Pendidikan Ekonomi (JPPE) Vol. 7 No. 2 (2016). Universitas Pendidkan Ganesha Singaraja Bali.

Sitio, Arifin, dan Haloman Tamba. 2001. Koperasi (Teori dan Praktek). Erlangga. Jakarta

Sopiah. 2008. Perilaku Organisasi. Andi Offset. Yogyakarta.

Sugiastini, Ida Ayu Febry dan Ni Nyoman Yuliarmi. 2015. Pengaruh Partisipasi Anggota Terhadap Keberhasilan Koperasi Serba Usaha di Kota Denpasar. E-Jurnal EP Unud Vol. 4 No. 3: 210-219. ISSN: 2303-0178. Universitas Udayana Bali.

Sugiyono. 2013. Metode Penelitian Kuantitatif, Kualitatif, dan Kombinasi (Mix Method). Alfabeta. Bandung. 2014. Metode Penelitian Manajemen. Alfabeta. Bandung.

Sutrisno, Edy. 2009. Manajemen Sumber Daya Manusia. Prenadamedia Group. Jakarta.

Yuliardi, Ricki dan Zuli Nuraeni. 2017. Statistika Penelitian: Plus Tutorial SPSS. Innosain. Yogyakarta. 